Article

\title{
Saxitoxin Modulates Immunological Parameters and Gene Transcription in Mytilus chilensis Hemocytes
}

\section{Allisson Astuya ${ }^{1}$, Crisleri Carrera ${ }^{1}$, Viviana Ulloa ${ }^{1}$, Ambbar Aballay ${ }^{1}$, Gustavo Núñez-Acuña ${ }^{2}$, Hélène Hégaret ${ }^{3}$ and Cristian Gallardo-Escárate ${ }^{2, *}$}

1 Laboratory of Cell Culture and Marine Genomics, Marine Biotechnology Unit, Faculty of Natural and Oceanographic Sciences and Program COPAS Sur-Austral, University of Concepción, Concepción 4070386, Chile; E-Mails: aastuya@udec.cl (A.As.); crislericarrera@udec.cl (C.C.); viulloa@udec.cl (V.U.); amaballay@udec.cl (A.Ab.)

2 Laboratory of Biotechnology and Aquatic Genomics, Interdisciplinary Center for Aquaculture Research (INCAR), University of Concepción, Concepción 4070386, Chile; E-Mail: gustavonunez@udec.cl

3 Laboratoire des Sciences de l'Environnement Marin (LEMAR), UMR 6539 CNRS/UBO/IRD/IFREMER, Institut Universitaire Européen de la Mer, Technopole Brest Iroise, 29280 Plouzané, France; E-Mail: helene.hegaret@univ-brest.fr

* Author to whom correspondence should be addressed; E-Mail: crisgallardo@udec.cl; Tel.: +56-41-2203422; Fax: +56-41-2204402.

Academic Editor: Lin Li

Received: 11 January 2015 / Accepted: 14 May 2015 / Published: 6 July 2015

\begin{abstract}
Saxitoxin (STX) is a neurotoxin produced by dinoflagellates in diverse species, such as Alexandrium spp., and it causes paralytic shellfish poisoning (PSP) in humans after the ingestion of contaminated shellfish. Recent studies have suggested that the immune functions of bivalves could be affected by harmful algae and/or by their toxins. Herein, hemocytes are the main effector cells of the immune cellular response. In this study, we evaluated the response of hemocytes from the mussel Mytilus chilensis to STX exposure in a primary culture. Cell cultures were characterized according to size and complexity, while reactive oxygen species (ROS) production was evaluated using a dichlorofluorescein diacetate (DCFH-DA) assay. Finally, phagocytic activity was measured using both flow cytometry and fluorescence microscopy assays. Additionally, gene transcription of candidate genes was evaluated by qPCR assays. The results evidenced that exposures to different concentrations of STX (1-100 nM) for $24 \mathrm{~h}$ did not affect cell viability, as determined by an MTT assay.
\end{abstract}


However, when hemocytes were exposed for 4 or $16 \mathrm{~h}$ to STX $(1-100 \mathrm{nM})$, there was a modulation of phagocytic activity and ROS production. Moreover, hemocytes exposed to $100 \mathrm{nM}$ of STX for 4 or $16 \mathrm{~h}$ showed a significant increase in transcript levels of genes encoding for antioxidant enzymes (SOD, CAT), mitochondrial enzymes (COI, COIII, CYTB, ATP6, ND1) and ion channels $\left(\mathrm{K}^{+}, \mathrm{Ca}^{2+}\right)$. Meanwhile, C-type lectin and toll-like receptor genes revealed a bi-phase transcriptional response after 16 and 24-48 h of exposure to STX. These results suggest that STX can negatively affect the immunocompetence of M. chilensis hemocytes, which were capable of responding to STX exposure in vitro by increasing the mRNA levels of antioxidant enzymes.

Keywords: saxitoxin; hemocytes; immune response; paralytic shellfish poisoning; reactive oxygen species (ROS)

\section{Introduction}

Harmful algal blooms (HABs) are excessive accumulations of phytoplankton that produce biotoxins, which can adversely affect humans, animals and ecosystems. The effects of HABs on the physiology of bivalves can result for example in reductions in filtration activity, changes in valve closure, paralysis of the adductor muscle, mantle retraction, increases in mucus production or erratic cardiac activity [1-6]. There are differences in the resistance of different species of bivalves to STX [7], which also is associated with differences in the ability to accumulate these toxins [8,9]. Although Mytilus spp. are considered refractory to contamination with paralytic shellfish toxins (PST), accumulating high concentrations of toxins in their tissues, there are reports of negative effects of PST in these bivalves [10-12]. In addition to this, histopathological lesions occur in bivalves exposed to $\mathrm{HAB}$ species through the degranulation and diapedesis of hemocytes into the alimentary canal and through hemocyte migration into connective tissue, which suggests an immune response similar to the inflammation process $[2,13,14]$.

In bivalves, the humoral and cellular immune responses are mediated by hemocytes and involve diverse cellular processes, such as phagocytosis, reactive oxygen species (ROS) production, opsonization, nodule formation and the release of immune mediators [15]. In vivo and in vitro studies have reported changes in cell morphology, increases in mortality, reductions in phagocytosis, changes in adhesion and ROS production in hemocytes after exposure to marine toxins derived from HABs, thereby indicating that the immune response to toxic microalgae could be directly related to toxin levels [16-18]. In addition to cellular immune parameters, changes occur at the transcriptional level of stress response genes in hemocytes exposed to marine toxins $[16,17,19]$. Furthermore, a transcriptional response was observed in Mytilus chilensis exposed in vivo to saxitoxin (STX), specifically through an increase in the mRNA levels of superoxide dismutase (SOD), catalase (CAT), ferritin and heat-shock protein genes, while, to a lesser extent, ependymin, fibrinogen-like, galectin and mytilin $B$ genes evidenced differentiated expressions after toxin exposure [20]. A complete review summarizing the molecular responses of bivalve species to phycotoxins was published in 2012, including the effects of STX exposure in marine environments [21]. Nonetheless, previous studies are focused only on in vivo assays and do not include 
in vitro assays, which would be helpful in developing standardized methods for evaluating the responses of diverse organisms to marine toxins and HABs. Furthermore, the fact that this species is considered a sentinel species for biomonitoring and even with the high amount of knowledge regarding the "omics" approaches to marine bivalves, there are more expectations for integrative studies focusing the response of marine bivalves on xenobiotics [22]. In this context, the integration of in vivo and in vitro approaches is still scarce.

In Chile, Alexandrium spp. are the species most associated with HABs [23-25]. Species of the genus Alexandrium are the main producers of paralytic shellfish poisoning (PSP) toxins, with saxitoxin as the most toxic analogue [26,27]. Studies using M. chilensis exposed to Alexandrium catenella have shown that this species is capable of a rapid response and has a great capacity for toxin acclimation. The mussel M. chilensis is of particular interest given its ecological and commercial importance to the Austral Region of Chile, where over 180,000 tons are annually produced through suspended cultivation and where HABs are very frequent [28]. Therefore, M. chilensis could be a good model to study the effects of STX on hemocytes.

The aim of this study was to evaluate the effects of saxitoxin on cellular and molecular responses in a primary culture of hemocytes from M. chilensis. For this, we analyzed cellular parameters, such as phagocytosis and ROS production, and changes at the transcriptional level for antioxidant enzymes, mitochondrial proteins, ion channels and pattern recognition receptor (PRR).

\section{Results}

\subsection{Primary Culture of Hemocytes from M. chilensis}

Hemocytes cultured from $M$. chilensis had a round-shape or a flattened polygonal shape with granules (Figure 1A), and these adhered to the substrate $3 \mathrm{~h}$ after seeding. According to the morphological appearance of the cultured hemocytes, two main groups were identified, which could correspond to hyalinocyte and granulocyte-type cells. Hemocytes in the culture were viable up to seven days, as assessed by an MTT assay (data not shown). Hemocyte visualization by size (forward scatter, FSC) and internal complexity (side scatter, SSC) showed a distribution similar to a fresh hemolymph of M. chilensis (Figure 1B). Two separate hemocyte populations were observed in the primary cell cultures (Figure 1C). Granulocyte-type cells corresponded to $39.9 \% \pm 0.6 \%$ of total events analyzed. Hyalinocyte-type cells appeared less granular, smaller in size and represented $60.1 \% \pm 0.4 \%$ of the total events.

On the other hand, analysis using fluorescence microscopy, as assayed using FITC-labeled zymosan particles, showed an evidently higher percentage of phagocytic hemocytes in controls than in hemocytes co-incubated with $2 \%$ sodium azide, a phagocytosis inhibitor (Figure 1D,E). Flow cytometry analysis evidenced different phagocytic activity for granulocytes and hyalinocytes after incubation with zymosan-FITC particles and co-incubation with zymosan-FITC and sodium azide (Figure 1F,G). Phagocytic cells represented $74.0 \% \pm 0.9 \%$ of the granulocytes, and phagocytic activity decreased to $36.9 \% \pm 2.7 \%$ with sodium azide. In contrast, phagocytic hyalinocytes accounted for $19.3 \% \pm 0.5 \%$, and phagocytic activity decreased to 11.3 , while phagocytic activity decreased to $0.7 \%$ with sodium azide. 

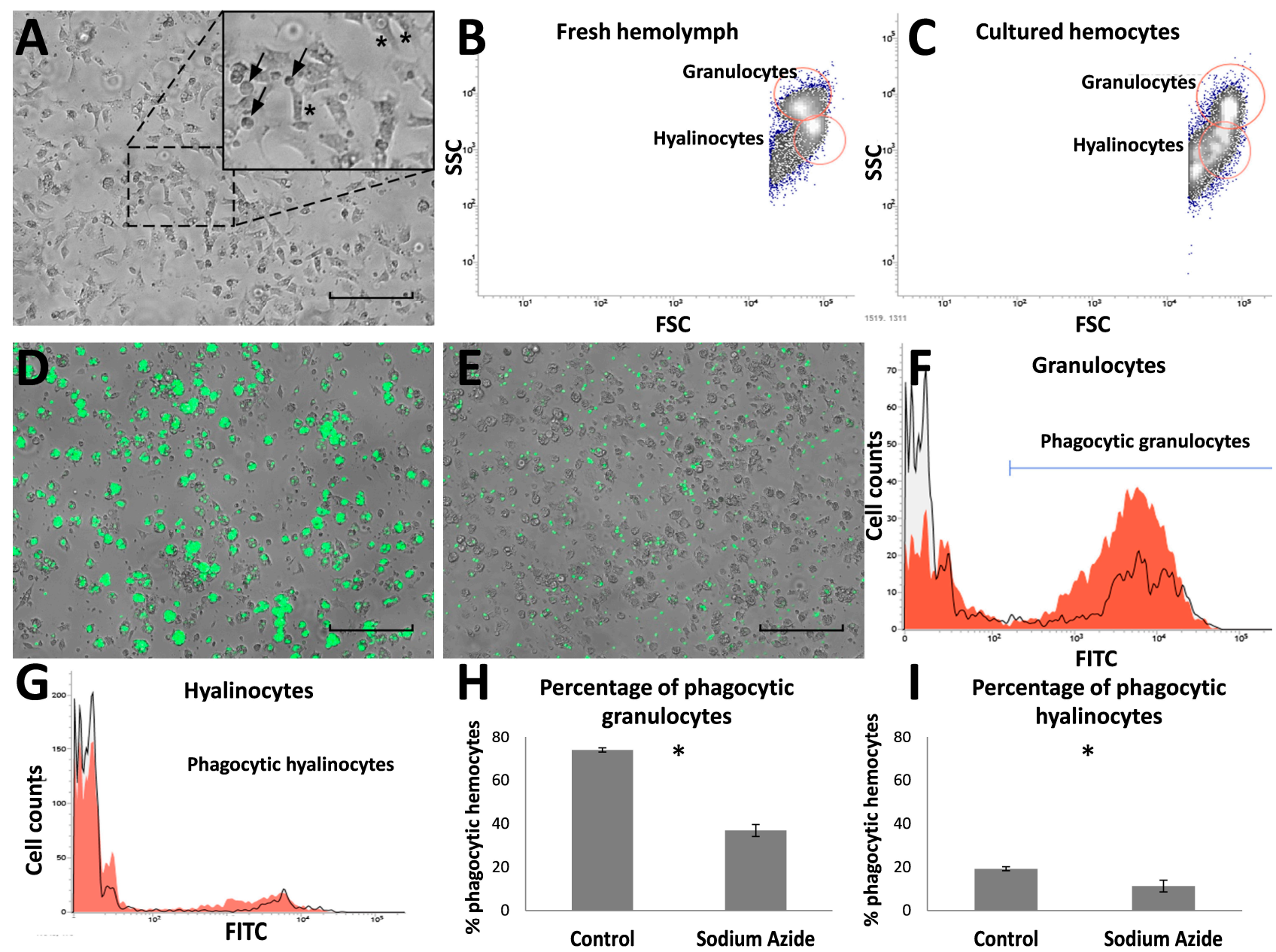

Figure 1. Characterization of Mytilus chilensis hemocytes in primary cell culture. (A) Light microscopy image. Insert: Granulocyte-type hemocytes (asterisks) and hyalinocyte-type hemocytes (arrows), Scale bar $=100 \mu \mathrm{m} ;(\mathbf{B}, \mathbf{C})$ Flow cytometry analyses of fresh $(\mathbf{B})$ and cultured (C) hemocytes showing both granulocyte-type and hyalinocyte-type hemocytes appearing in the red circles; (D) Fluorescence microscopy image of phagocytosis assay on hemocytes incubated with $0.2 \%$ FITC-labeled zymosan (green) for $1 \mathrm{~h}$, Scale bar $=100 \mu \mathrm{m}$; (E) Inhibition of phagocytosis with $2 \%$ sodium azide, Scale bar $=100 \mu \mathrm{m} ;(\mathbf{F}, \mathbf{G})$ Phagocytosis of $0.2 \%$ FITC-labeled zymosan after $1 \mathrm{~h}$ observed in granulocytes $(\mathbf{F})$ and hyalinocytes $(\mathbf{G})$. The red lines correspond to phagocytosis of control hemocytes, and the overlaid black lines correspond to phagocytosis of hemocytes incubated with sodium azide showing inhibition; $(\mathbf{H}, \mathbf{I})$ Effect of $2 \%$ sodium azide on the phagocytic activity of granulocyte-type $(\mathbf{H})$ and hyalinocyte-type $(\mathbf{I})$ hemocytes. Bars represent the mean \pm standard errors $(n=4) .{ }^{*} p<0.05$.

\subsection{Effects of Saxitoxin (STX) on Cellular Parameters}

The percentage of phagocytic cells in the control condition was $72.3 \%$, whereas phagocytosis was inhibited at $80 \%$ with sodium azide. A decrease in the percentage of phagocytic cells was observed after 4 and $16 \mathrm{~h}$ of exposure to STX (Figure 2). The percentage of phagocytic cells was reduced by 
approximately $30 \%$ after $4 \mathrm{~h}$ and by $50 \%$ after $16 \mathrm{~h}$ of incubation with STX, compared to the control. However, there was no dose-dependent effect of STX (Figure 2).

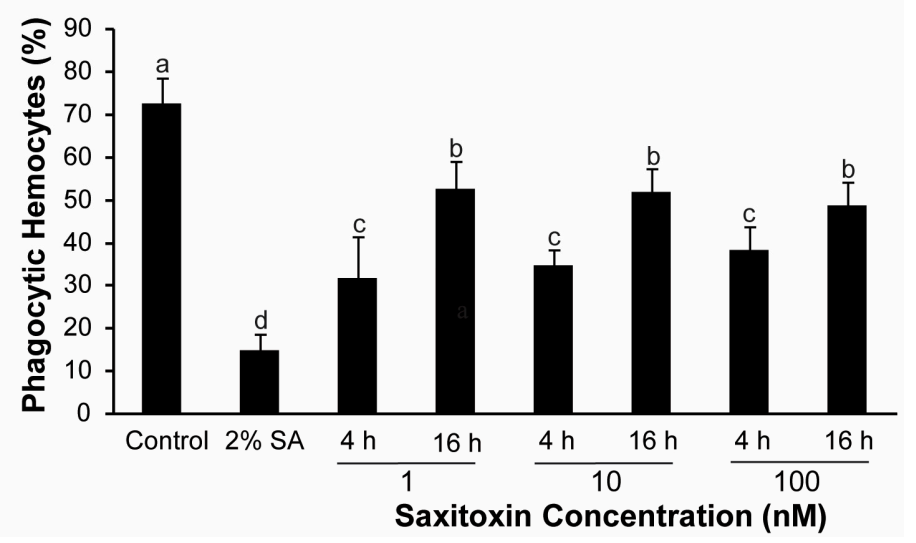

Figure 2. Effect of saxitoxin (STX) on the phagocytic activity of hemocytes. Hemocytes were pre-incubated with STX for 4 or $16 \mathrm{~h}$ and then incubated with $0.2 \%$ FITC-labeled zymosan for $1 \mathrm{~h}$ at $20{ }^{\circ} \mathrm{C}$ or co-incubated with $2 \%$ sodium azide. Phagocytic cells were analyzed by fluorescence microscopy. Bars represent the mean \pm standard errors $(n=3$ cultures of hemocytes). Different superscripts indicate statistically-significant differences $(p<0.05$; Kruskal-Wallis/Mann-Whitney) at 4 and $16 \mathrm{~h}$ after incubation with STX as compared to the control group. SA: Sodium azide.

On the other hand, hemocytes stimulated with phorbol myristate acetate (PMA) showed a higher production of intracellular ROS at 4 and $16 \mathrm{~h}$, compared to hemocytes incubated without PMA. At $4 \mathrm{~h}$, there was no significant effect of STX in PMA-stimulated hemocytes (Figure 3A). However, a decrease in ROS production was observed at $16 \mathrm{~h}$ in cells exposed to 1 and $10 \mathrm{nM} \mathrm{STX}$, but there was an increase at $100 \mathrm{nM} \mathrm{STX} \mathrm{(Figure} \mathrm{3B).}$
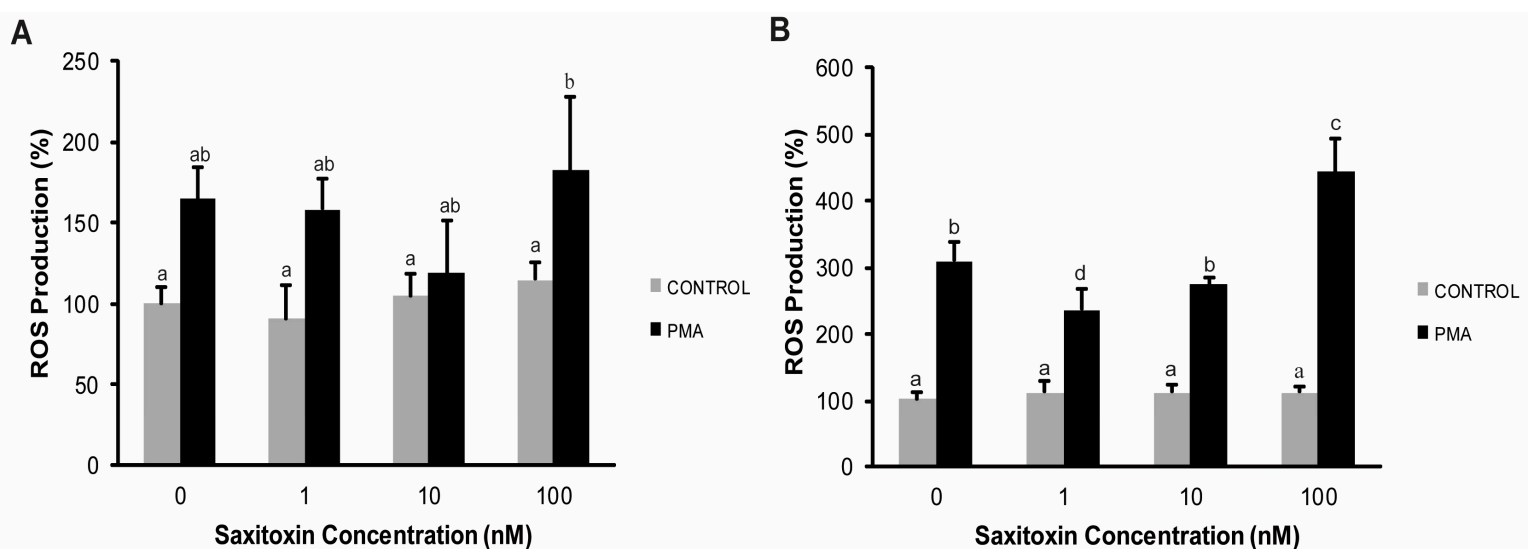

Figure 3. Evaluation of STX effects on reactive oxygen species (ROS) production in hemocytes. Cells were incubated with STX for (A) $4 \mathrm{~h}$ or (B) $16 \mathrm{~h}$ and later incubated with $10 \mu \mathrm{M}$ dichlorofluorescein diacetate (DCFH-DA) for $90 \mathrm{~min}$. PMA: Cells stimulated with $10 \mu \mathrm{g} \cdot \mathrm{mL}^{-1}$ PMA. Bars represent the mean \pm standard errors $(n=3$ cultures of hemocytes). Different superscripts indicate statistically significant differences $(p<0.05)$ at 4 (ANOVA/Tukey HSD) and $16 \mathrm{~h}$ (Kruskal-Wallis/Mann-Whitney) after incubation. 


\subsection{Effects of STX on the Gene Expression of Antioxidant Enzymes, Oxidative Phosphorylation} Transcripts, Ion Channels and Pattern Recognition Receptors

Gene transcription levels of antioxidant enzymes showed a significant increase after the incubation of hemocytes with $100 \mathrm{nM}$ STX for $16 \mathrm{~h}$. The mRNA levels of SOD, CAT and ferritin increased after $16 \mathrm{~h}$, while the expression level of metallothionein increased at 4 and $16 \mathrm{~h}$. Besides this, hemocytes incubated with STX, regardless of concentration or time, showed similar expression levels of mitochondrial enzymes, such as COI, COIII, CytB, ATP6 and ND1, which were more expressed than in cells without STX at both times analyzed. In the case of ion channel genes, increased expression levels were observed at 4 and $16 \mathrm{~h}$ for $\mathrm{K}^{+}$and $\mathrm{Ca}^{2+}$ channels. This was especially evidenced for the $K^{+}$channel at $16 \mathrm{~h}$, which showed a four-fold increase as compared to control cells. Conversely, $V D A C$ transcripts evidenced decreased expression levels after $16 \mathrm{~h}$ of exposure to STX (Figure 4). Nucleotide alignments and BLAST analyses evidenced that these last three transcripts corresponded to the subtype of "voltage-dependent channels", also known as "voltage-gated channels".

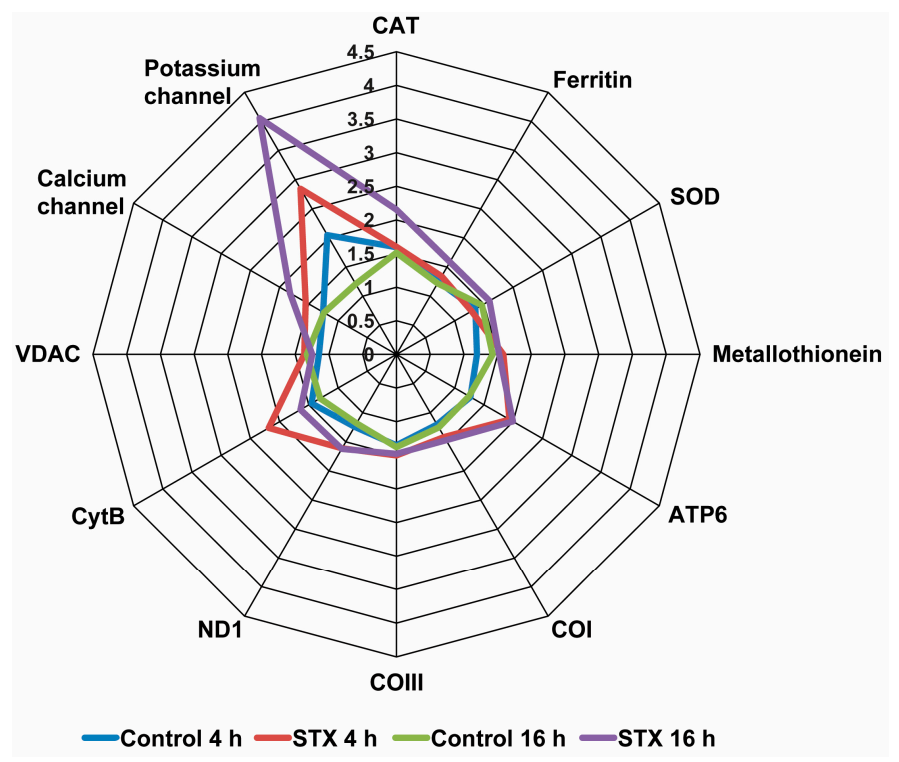

Figure 4. Radial graph of relative transcript levels for studied genes in cultured hemocytes after exposure to STX or a control solution. Cells were seeded in six-well plates, and after three days of culturing, cells were incubated with $100 \mathrm{nM}$ STX for 4 or $16 \mathrm{~h}$.

With respect to C-type lectin and toll-like receptor genes, the transcriptional activity revealed a bi-phase transcriptional response that decreased after $16 \mathrm{~h}$, but then increased again from $24-48 \mathrm{~h}$ post-exposure to STX (Figure 5).

The transcript annotated as TLR that was evaluated by qPCR in this study corresponded to an orthologous sequence to the $T L R-b$ gene reported by Toubiana et al. [29]. This transcript shared $99.8 \%$ of identity with the gene described for Mytilus galloprovincialis (GenBank Accession Number JX173687). On the other hand, the C-type lectin gene corresponded to the subtype GalNAc/Gal-specific lectin. 

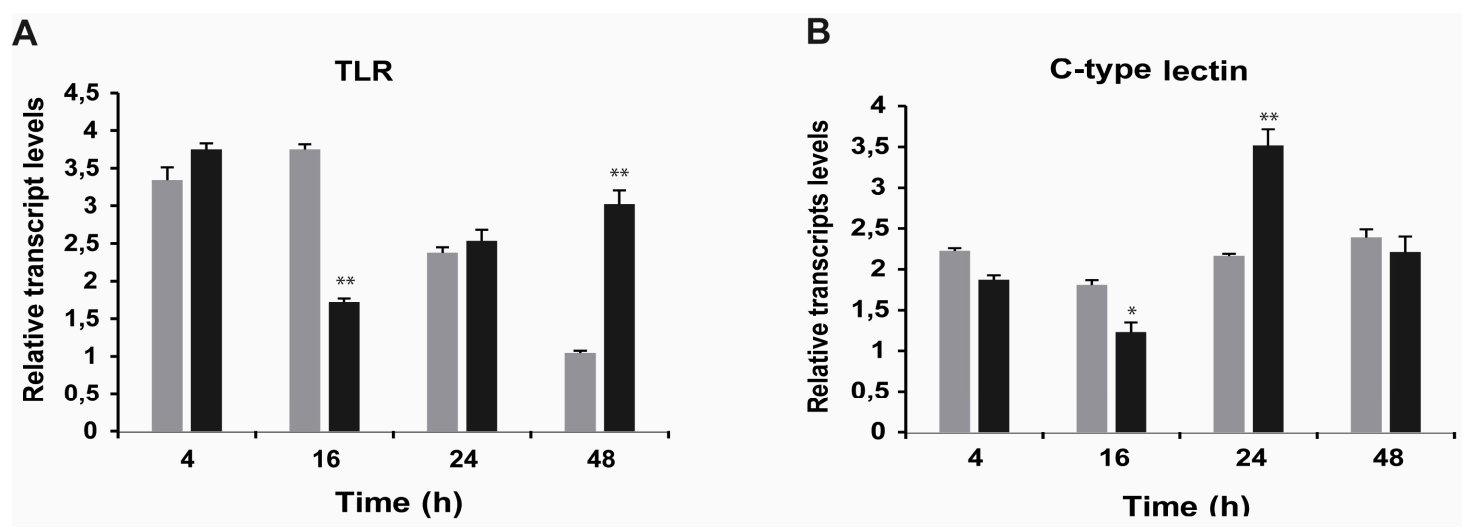

Figure 5. Relative transcript levels for studied genes (TLR (A) and C-type lectin (B)) of the pattern recognition receptor (PRR) in cultured hemocytes after exposure to STX. Cells were seeded in six-well plates, and after three days of culturing, cells were incubated with $100 \mathrm{nM}$ STX for 4, 16, 24 or $48 \mathrm{~h}$. Black bars = Challenged hemocytes (STX exposed); grey bars $=$ Control hemocytes (mean $\pm \mathrm{SE}, n=4$ cultures of hemocytes). ${ }^{*} p<0.05$ and ** $p<0.01$ represent statistical differences at 4, 16, 24 and $48 \mathrm{~h}$ after incubation with STX as compared to the control group (ANOVA/Tukey HSD).

\section{Discussion}

\subsection{Characterization of Hemocyte Primary Cell Cultures}

Cultured hemocytes mainly showed two morphological types: (i) Larger cells with star and spindle shapes with the clear presence of granules and signs of adherence to the culture surface; and (ii) Less adherent spherical cells. These cell types would correspond to granulocyte-like and hyalinocyte-like cells described from other primary cultures of molluscan hemocytes [30,31]. Flow cytometry analysis strongly supported this hypothesis, by evidencing that the cell types found in this study were similar to those observed in samples from a fresh M. chilensis hemolymph and other previously reported mussel hemocytes [15,32-35].

Although morphological microscopy analysis showed these primary cultures to be enriched with granulocyte-like cells, flow cytometry quantification provided a lower proportion of this cell type (data not shown). These results are similar to previous studies showing a $40 \%$ decrease in the total number of hemocytes when analyzed by flow cytometry [36]. Although flow cytometry analysis showed a lower proportion of granulocyte-like cells, these cells exhibited higher phagocytic activity, supporting the assumption that these differences could be directly related to the processing of samples for flow cytometry, which could produce the loss of granulocyte-like cells. Furthermore, another validation for the functionality of our primary cultures was conducted to measure the activation of the immune response to the PMA inductor [37-39], which indicated a significant increase in ROS production after stimulation.

\subsection{Cellular Response of Hemocytes to STX Exposure}

Regarding the effect of STX on the primary culture of hemocytes, an absence of the cytotoxic effects can be noted between the dosage range of $1-100 \mathrm{nM}$ over $24 \mathrm{~h}$ of exposure. These results are consistent 
with results from in vitro studies on fresh hemocytes, although these studies were performed with lower toxin concentrations and shorter incubation times [16,17].

STX did however affect hemocyte functions. The inhibitory effect of STX on nearly $50 \%$ of active phagocytic cells at $4 \mathrm{~h}$, as determined by fluorescence microscopy, was comparatively higher than the effects observed in another study using isolated hemocytes and flow cytometry [16], thus supporting the assumption that there was a loss of activated cells during sample handling for flow cytometry assays [36]. Basal ROS production of unstimulated cells incubated with STX was not affected under any of the evaluated conditions, whereas a significant inhibition of ROS production was previously observed in unstimulated $C$. gigas hemocytes after STX incubation [16]. Taking into account the absence of STX effects on the basal ROS production of hemocytes, the stimulation of hemocytes with PMA was performed in order to analyze the STX effects. The results of this evaluation showed changes on ROS production in PMA-stimulated cells incubated with STX at $16 \mathrm{~h}$.

\subsection{Effects of STX on Gene Transcription in M. chilensis Hemocytes}

Undoubtedly, the most noticeable result of transcriptional analyses was the contrasting trend observed for the different voltage-gated ion channels. On the one hand, a decrease in the transcription levels of $V D A C$ was observed at $16 \mathrm{~h}$ post exposure. The $V D A C$ channel is one of the most important modulators of mitochondrial metabolism at the cellular level [40]. This would explain the absence of significant differences in the transcription levels of other mitochondrial genes, such as ATP6, COI, COIII and ND1, as well as the decrease in the transcription levels of $C y t B$ after $16 \mathrm{~h}$ of toxin exposure. On the other hand, transcription of calcium and potassium channels increased after 4 and $16 \mathrm{~h}$ of exposure to STX. This could be explained by the sodium channel not being the only channel to respond to STX, where instead, there is also a response of other channels. Moreover, the interactions of nucleotide mutations localized in sequences that encode ion channels [41] have also been demonstrated. Another hypothesis could be that this increased transcription of calcium and potassium channels is indeed an attempt to maintain cellular ion homeostasis.

With regards to the other measured genes, an overexpression of antioxidant transcripts ( $S O D, C A T$ and ferritin) was observed after STX exposure. This is consistent with previous research showing a similar gene pattern in mussels exposed in vivo to STX [20]. Furthermore, pattern recognition receptors (PRR), such as C-type lectin and toll-like receptor, revealed a bi-phase transcriptional response, decreasing after $16 \mathrm{~h}$ and then increasing after 24-48 h exposure to STX. Although the study of PRR against marine toxins is limited, the recognition process through these pathogens and PAMP receptors in marine invertebrate hemocytes has already been described [42-45]. Overexpression of genes might suggest that STX is recognized as an invasive foreign molecule by the immune system of M. chilensis, which could act as a PAMP-type molecule. Nonetheless, further analyses are needed to establish a quantitative relationship between in vitro and in vivo models given the different experimental approaches, and, in this case, the different geographic zones of sampled species.

\subsection{Use of Primary Hemocyte Cultures in Toxicological Studies}

Establishing a primary culture of bivalve hemocytes allows for the analysis and long-term monitoring of different environmental pollutants and inductors under controlled conditions, thereby increasing 
accuracy and reproducibility [29,46-50]. Several authors have shown that stimulation of fresh hemocytes for $4 \mathrm{~h}$ is sufficient to evaluate the response to different environmental stressors, such as toxins, metals and chemical pollutants [47,51-53]. However, the use of fresh hemocytes limits the investigation to only a few hours. This long-term in vitro model thus also allows a more sensitive assay. Indeed, results after $4 \mathrm{~h}$ of in vitro incubation showed no significant effects of STX, which indeed appeared to demonstrate the regulation of cell function in M. chilensis hemocytes after $16 \mathrm{~h}$ of STX exposure. Thus, in addition to accuracy and reproducibility, the establishment of the long-term primary culture of bivalve hemocytes also confers a more sensitive assay to demonstrate the impact of any environmental pollutants and inductors, via regulation of hemocyte function after several hours' exposure. Future usage of cell cultures could also clarify the mechanisms used by M. chilensis to bioaccumulate high concentrations of toxins, unlike other bivalves, such as oysters [28,54]. Additionally, by using primary cell cultures of hemocytes, early biomarkers of pollution could be identified and subsequently used in sentinel organisms, such as M. chilensis.

\section{Experimental Section}

\subsection{Primary Culture of Hemocytes}

The primary culture protocol was modified from Cao et al. [30,55]. Mussels $M$. chilensis averaging $8 \mathrm{~cm}$ in shell length were used; and these were kept on ice during hemolymph collection. Hemolymph was extracted from the adductor muscle using a 25 Gauge needle and a syringe and was placed into centrifuge tubes with Alseve's buffer $(382 \mathrm{mM} \mathrm{NaCl}, 27 \mathrm{mM}$ sodium citrate, $11.5 \mathrm{mM}$ EDTA and $115 \mathrm{mM}$ glucose, $\mathrm{pH} 7$ ). Then, the hemolymph was centrifuged at $600 \times \mathrm{g}$ for $10 \mathrm{~min}$ at $4{ }^{\circ} \mathrm{C}$. The supernatant was removed, and the pellet was resuspended in an $\mathrm{L}-15$ culture medium supplemented with $350 \mathrm{mM} \mathrm{NaCl}, 7.2 \mathrm{mM} \mathrm{KCl}, 5.5 \mathrm{mM} \mathrm{CaCl}_{2}, 8.3 \mathrm{mM} \mathrm{MgSO}_{4}, 40 \mathrm{mM} \mathrm{MgCl}_{2}, 115 \mathrm{mM}$ glucose, $2 \mathrm{mM}$ L-glutamine, $300 \mathrm{IU} \cdot \mathrm{mL}^{-1}$ penicillin, $300 \mu \mathrm{g} \cdot \mathrm{mL}^{-1}$ streptomycin, $30 \mu \mathrm{g} \cdot \mathrm{mL}^{-1}$ gentamicin and $0.45 \mathrm{mg} \cdot \mathrm{mL}^{-1}$ amphotericin-B, $\mathrm{pH}$ 7.4. A total of $60 \times 10^{6}$ cells were obtained from approximately 20 mussels. Hemocytes were plated in a cellular density range of $2-4 \times 10^{6}$ cells $\cdot \mathrm{mL}^{-1}$ and kept at $4{ }^{\circ} \mathrm{C}$. The experiments were performed on the third day of culture.

\subsection{Experimental Design}

For different analyses, hemocytes were incubated for 4 or $16 \mathrm{~h}$ with STX at final concentrations of 1 , 10 or $100 \mathrm{nM}$. The solution of STX dihydrochloride (NRC-Canada, Ottawa, ON, Canada) was prepared by diluting a standard solution in supplemented L-15. Cells were incubated at $4{ }^{\circ} \mathrm{C}$ in the dark.

\subsection{Viability and Phagocytosis Assays Using Light and Fluorescent Microscopy}

To determine hemocyte viability, $6 \times 10^{5}$ hemocytes were seeded into 96-well plates and maintained in culture at $4{ }^{\circ} \mathrm{C}$. After 3 days of culture, hemocytes were incubated for $24 \mathrm{~h}$ with a solution of $2.5 \mathrm{mg} / \mathrm{mL}$ 3-(4.5-dimethylthiazol-2-yl)-2.5-diphenyltetrazolium bromide (MTT; Life Technologies, Eugene, OR, USA). The medium was removed, and $100 \mu \mathrm{L}$ of dimethyl sulfoxide were then added into each well. The plates were read using a microplate reader (Synergy H1, BioTek, Winooski, VT, USA) at $570 \mathrm{~nm}$. 
For phagocytosis assays, three replicates of $1 \times 10^{6}$ cells were plated into 24 -well plates. FITC-labeled particles of zymosan (Life Technologies) were added to a final concentration of $0.2 \%$. Sodium azide (2\%), a phagocytosis inhibitor [56], was used as a negative control. Plates were maintained in the dark at $4{ }^{\circ} \mathrm{C}$ for $1 \mathrm{~h}$. Finally, three images per replicate were taken on a fluorescence microscope (Floid ${ }^{\circledR}$ Cell Image Station, Life Technologies). To assess the percentage of phagocytosis, 200 cells per well were counted.

\subsection{Hemocyte Phagocytosis Using Flow Cytometry}

Flow cytometry analyses were performed in order to assess the phagocytosis rate. Thus, four replicates of $1 \times 10^{6}$ hemocytes from each well were harvested using trypsin $(0.25 \%)$ after incubation with zymosan particles. Cells were resuspended in supplemented L-15, transferred to $5 \mathrm{~mL}$ flow-cytometer tubes and kept on ice. Flow cytometry analyses were performed using a FACSAria III flow cytometer (BD Biosciences, San José, CA, USA), with 10,000 events analyzed per sample. Data were later analyzed using the flow cytometry analysis software BD FACSDiva (BD Biosciences).

\subsection{Intracellular ROS Production Using Fluorescent Microscopy}

The production of ROS was determined using 2'7'-dichlorofluorescein diacetate (DCFH-DA; Life Technologies), a non-fluorescent and membrane-permeable probe. After oxidation, the probe converts into the highly fluorescent DCF. Hemocytes $\left(1 \times 10^{5}\right.$ cells $)$ cultured in 96 -well plates were incubated with $10 \mu \mathrm{M}$ DCFH-DA. ROS production was stimulated with $10 \mu \mathrm{g} \cdot \mathrm{mL}^{-1}$ phorbol myristate acetate (PMA; Sigma-Aldrich, Saint Louis, MO, USA) [57]. Measurements of three replicates were conducted every $30 \mathrm{~min}$ for $90 \mathrm{~min}$ at $20^{\circ} \mathrm{C}$ using a microplate reader (Sinergy H1, BioTek).

\subsection{Transcription Expression of Candidate Genes}

For qPCR analyses, $8 \times 10^{6}$ hemocytes were incubated in 6-well plates with $100 \mathrm{nM}$ STX for 4 or $16 \mathrm{~h}$. Total RNA was extracted from each well using the TRIzol reagent (Life Technologies) following the manufacturer's instructions. The quantity, purity and quality of isolated RNA were measured using a microplate reader (Synergy H1, BioTek). Subsequently, double-stranded cDNA was synthesized using the RevertAid H Minus First Strand cDNA Synthesis Kit (Thermo Scientific, Waltham, MA, USA). Moreover, five serial dilutions of cDNA stocks were conducted to establish the dynamic range for the genes under study. Enzyme efficiency between $90 \%$ and $110 \%$ in all reactions was obtained. Subsequently, a pool of samples from each experiment was used to select the best housekeeping gene according to its stability value inferred by the GeNorm application [58]. Three housekeeping genes were analyzed: $28 S$, elongation factor $\alpha$ and $\alpha$-tubulin, of which the latter was the most stable at the moment of analyzing its stability value. Subsequently, a gene expression analysis was conducted using the comparative $\Delta \Delta C_{\mathrm{t}}$ method, with 3 replicates for each experiment, and normalizing the expression data of each target gene with the $\alpha$-tubulin endogenous control data. All reactions for dynamic range, endogenous validation and expression analysis were conducted using the Maxima $\mathrm{Kit}^{\circledR}$ SYBR Green/ROX qPCR Master Mix (2×) (Fermentas, Waltham, MA, USA), according to the manufacturer's instructions and using a primer concentration of $500 \mathrm{nM}$ and a 1:5 dilution for each cDNA stock. qPCR 
was performed on an Eco Real-Time PCR System (Illumina, San Diego, CA, USA), and all gene expression analyses were performed using 3 biological replicates from each experiment. Specific primers were designed to amplify candidate genes related to immune response, such as antioxidant enzymes, oxidative phosphorylation transcripts, ion channels and pattern recognition receptors. Herein, CAT, SOD, ferritin, metallothionein, NADH dehydrogenase 1 (ND1), ATP6, cytochrome oxidase subunit I (COI), cytochrome oxidase subunit III (COIII), cytochrome B (CytB), voltage-dependent anion channel (VDAC), $\mathrm{Ca}^{2+}$ channel, $\mathrm{K}^{+}$channel, $C$-type lectin and toll-like receptor (TLR). The sequence information to design PCR primers and to evaluate their transcription expression was obtained from an EST-database generated by high-throughput sequencing from M. chilensis [59]. The list of oligonucleotide primers used to amplify target genes is shown in Table 1. Statistical analysis was performed using the Statistica software (Version 7.0, StatSoft, Inc., Tulsa, OK, USA).

Table 1. Gene names, forward and reverse primer sequences for real-time quantitative PCR (qPCR) analysis and references.

\begin{tabular}{|c|c|c|}
\hline Gene & Primers $\left(5^{\prime}-3^{\prime}\right)$ & Reference \\
\hline Catalase & $\begin{array}{c}\text { CCAGGTGTCCTTCCTGTTTTCT } \\
\text { TGTCCATCCTTGTTGACTGTCTTAA }\end{array}$ & Núñez-Acuña et al., 2012 [60] \\
\hline$E c-S O D C u / Z n$ & $\begin{array}{c}\text { TCGCTTTCAGTCAACAGAATGG } \\
\text { CCAAACTCGTGAACGTGGAA }\end{array}$ & Núñez-Acuña et al., 2012 [60] \\
\hline Ferritin & $\begin{array}{c}\text { CAAGTGAACGCCATCAAGGA } \\
\text { CGTTGATGCTCTCTTTGTCATACA }\end{array}$ & Núñez-Acuña et al., 2012 [60] \\
\hline Metallothionein & $\begin{array}{l}\text { CTGTGGTGACGCCTGCAAGT } \\
\text { CTGTGGTGACGCCTGCAAGT }\end{array}$ & Núñez-Acuña et al., 2013 [20] \\
\hline NADH dehydrogenase I & $\begin{array}{c}\text { CTTACTAGGTGCAGTCCGTG } \\
\text { ACATAAACACGCCTGAAGATAGT }\end{array}$ & Primers designed in this study \\
\hline ATP6 & $\begin{array}{c}\text { TGGGCATACCGCTGTGACTTACT } \\
\text { GTGCAGGGGCACCCATAGGA }\end{array}$ & Primers designed in this study \\
\hline Cytochrome oxidase subunit I & $\begin{array}{c}\text { TCAGCTGCTGTAGAGAGTGGGG } \\
\text { TCACGCCGGTGGTTCAGTTG }\end{array}$ & Primers designed in this study \\
\hline Cytochrome oxidase subunit III & $\begin{array}{l}\text { TATGTACCAGGCCCAAGTCC } \\
\text { AAAATCTGGGGGTTCGATGC }\end{array}$ & Primers designed in this study \\
\hline Cytochrome B & $\begin{array}{c}\text { GGAAGATGCCCGTTGGAGGC } \\
\text { CCCTGCGCTCCAGAAATTATGGG }\end{array}$ & Primers designed in this study \\
\hline Voltage-dependent anion channel & $\begin{array}{l}\text { CAGACAGGAAAGAAGCAGGG } \\
\text { CTAAGGCACCATTCACAGCT }\end{array}$ & Primers designed in this study \\
\hline Calcium channel & $\begin{array}{c}\text { TGTAAGCAAGTCGTGTGGGGCAC } \\
\text { ACGAGTTTGGGCAGACTATGATCCTG }\end{array}$ & Primers designed in this study \\
\hline Potassium channel & $\begin{array}{l}\text { CGGCAATTTGGACCGGGCTTGTG } \\
\text { GCGCCCTCTGTCCATTACTCGGC }\end{array}$ & Primers designed in this study \\
\hline C-type lectin & $\begin{array}{l}\text { GATATCGCTGTGCAGAACCA } \\
\text { AAACACAAGGCCAGTGGAAA }\end{array}$ & Primers designed in this study \\
\hline$T L R$ & $\begin{array}{c}\text { CTTTCTTAGCCACGCCAGAC } \\
\text { TGTCATTGTCATTGTCAGTTTCGTCA }\end{array}$ & Primers designed in this study \\
\hline$\alpha$-Tubulin & $\begin{array}{l}\text { GAGCCGTCTGCATGTTGAGC } \\
\text { TGGACGAAAGCACGTTTGGC }\end{array}$ & Núñez-Acuña et al., 2012 [60] \\
\hline
\end{tabular}




\subsection{Statistical Analyses}

All statistical analyses were performed using the Statistica 10.0 (StatSfot) software. In order to assess the normality of the data, a Shapiro-Wilk test was conducted. When data followed a normal distribution, a one-way analysis of variance (ANOVA) followed by a post hoc Tukey HSD was performed. For non-parametric data, Kruskal-Wallis was used, followed by a Mann-Whitney test to compare between groups. Differences were considered significant when $p<0.05$, represented with a, b, c, d superscripts or with an asterisk. In the case of relative gene expression, significant differences were represented with an asterisk.

\section{Conclusions}

In this study, we demonstrated the usefulness of a metabolically- and functionally-active primary culture of hemocytes in analyzing the effects of STX on the cellular and transcriptional response. Using primary cultures of hemocytes would reduce the interferences associated with handling fresh hemolymph. Cultured hemocytes were sensitive to STX, similar to fresh hemocytes analyzed in vitro and in vivo. Granulocyte-like cells were those principally affected by STX, suggesting that the toxin might be capable of modulating the cellular immune response in a way similar to other inductors, including foreign particles, pathogens and toxic microalgae. The transcriptional analysis used in this in vitro model could provide new perspectives for shellfish monitoring programs. However, more investigations are required.

\section{Acknowledgments}

The work is supported by FONDECYT research Grant No. 1120397 and FONDAP No. 15110027. The authors also thank Carla Vejar and the Center for Advanced Microscopy (CMA BIOBIO, Universidad de Concepción).

\section{Author Contributions}

Writing of the manuscript was conducted by Allisson Astuya, Crisleri Carrera, Viviana Ulloa, Ambbar Aballay, Gustavo Núñez-Acuña, Hélène Hégaret and Cristian Gallardo-Escárate. Furthermore, Cristian Gallardo-Escárate did the planning of the study, the full supervision and the submission tasks.

\section{Conflicts of Interest}

The authors declare no conflict of interest.

\section{References}

1. Perovic, S.; Tretter, L.; Brummer, F.; Wetzler, C.; Brenner, J.; Donner, G.; Schroder, H.C.; Muller, W.E. Dinoflagellates from marine algal blooms produce neurotoxic compounds: Effects on free calcium levels in neuronal cells and synaptosomes. Environ. Toxicol. Pharmacol. 2000, 8, 83-94.

2. Hegaret, H.; da Silva, P.M.; Sunila, I.; Shumway, S.E.; Dixon, M.S.; Alix, J.; Wikfors, G.H.; Soudant, P. Perkinsosis in the Manila clam Ruditapes philippinarum affects responses to the harmful-alga, Prorocentrum minimum. J. Exp. Mar. Biol. Ecol. 2009, 371, 112-120. 
3. Estrada, N.; Rodriguez-Jaramillo, C.; Contreras, G.; Ascencio, F. Effects of induced paralysis on hemocytes and tissues of the giant lions-paw scallop by paralyzing shellfish poison. Mar. Biol. 2010, 157, 1401-1415.

4. Navarro, J.M.; Contreras, A.M. An integrative response by Mytilus chilensis to the toxic dinoflagellate Alexandrium catenella. Mar. Biol. 2010, 157, 1967-1974.

5. Hegaret, H.; da Silva, P.M.; Wikfors, G.H.; Lambert, C.; de Bettignies, T.; Shumway, S.E.; Soudant, P. Hemocyte responses of Manila clams, Ruditapes philippinarum, with varying parasite, Perkinsus olseni, severity to toxic-algal exposures. Aquat. Toxicol. 2007, 84, 469-479.

6. Shumway, S.E. A review of the effects of algal blooms on shellfish and aquaculture. J. World Aquac. Soc. 1990, 21, 65-104.

7. Twarog, B.M.; Hidaka, T.; Yamaguchi, H. Resistance to tetrodotoxin and saxitoxin in nerves of bivalve molluscs. A possible correlation with paralytic shellfish poisoning. Toxicon 1972, 10, 273-278.

8. MacQuarrie, S.P.; Bricelj, V.M. Behavioral and physiological responses to PSP toxins in Mya arenaria populations in relation to previous exposure to red tides. Mar. Ecol. Prog. Ser. 2008, 366, 59-74.

9. Bricelj, V.M.; Lee, J.H.; Cembella, A.D.; Anderson, D.M. Uptake kinetics of paralytic shellfish toxins from the dinoflagellate Alexandrium fundyense in the mussel Mytilus edulis. Mar. Ecol. Prog. Ser. 1990, 63, 177-188.

10. Shumway, S.E.; Cucci, T.L. The effects of the toxic dinoflagellate Protogonyaulax tamarensis on the feeding and behaviour of bivalve molluscs. Aquat. Toxicol. 1987, 10, 9-27.

11. Shumway, S.E.; Pierce, F.C.; Knowlton, K. The effect of Protogonyaulax tamarensis on byssus production in Mytilus edulis L., Modiolus modiolus linnaeus, 1758 and Geukensia demissa dillwyn. Comp. Biochem. Physiol. A Physiol. 1987, 10, 1021-1023.

12. Galimany, E.; Sunila, I.; Hégaret, H.; Ramón, M.; Wikfors, G.H. Experimental exposure of the blue mussel (Mytilus edulis, L.) to the toxic dinoflagellate Alexandrium fundyense: Histopathology, immune responses, and recovery. Harmful Algae 2008, 7, 702-711.

13. Hegaret, H.; Smolowitz, R.M.; Sunila, I.; Shumway, S.E.; Alix, J.; Dixon, M.; Wikfors, G.H. Combined effects of a parasite, QPX, and the harmful-alga, Prorocentrum minimum on northern quahogs, Mercenaria mercenaria. Mar. Environ. Res. 2010, 69, 337-344.

14. Haberkorn, H.; Lambert, C.; le Goic, N.; Gueguen, M.; Moal, J.; Palacios, E.; Lassus, P.; Soudant, P. Effects of Alexandrium minutum exposure upon physiological and hematological variables of diploid and triploid oysters, Crassostrea gigas. Aquat. Toxicol. 2010, 97, 96-108.

15. Cheng, T.C. Hemocytes: Forms and functions. In The Eastern Oyster: Crassostrea Virginica; Kennedy, V.S., Newell, R.I., Eble, A.F., Eds.; University of Maryland Sea Grant Publications: College Park, MD, USA, 1996; pp. 299-333.

16. Mello, D.F.; da Silva, P.M.; Barracco, M.A.; Soudant, P.; Hegaret, H. Effects of the dinoflagellate Alexandrium minutum and its toxin (saxitoxin) on the functional activity and gene expression of Crassostrea gigas hemocytes. Harmful Algae 2013, 26, 45-51.

17. Mello, D.F.; de Oliveira, E.S.; Vieira, R.C.; Simoes, E.; Trevisan, R.; Dafre, A.L.; Barracco, M.A. Cellular and transcriptional responses of Crassostrea gigas hemocytes exposed in vitro to brevetoxin (PbTx-2). Mar. Drugs 2012, 10, 583-597. 
18. Prado-Alvarez, M.; Florez-Barros, F.; Mendez, J.; Fernandez-Tajes, J. Effect of okadaic acid on carpet shell clam (Ruditapes decussatus) haemocytes by in vitro exposure and harmful algal bloom simulation assays. Cell Biol. Toxicol. 2013, 29, 189-197.

19. Mat, A.M.; Haberkorn, H.; Bourdineaud, J.P.; Massabuau, J.C.; Tran, D. Genetic and genotoxic impacts in the oyster Crassostrea gigas exposed to the harmful alga Alexandrium minutum. Aquat. Toxicol. 2013, 140-141, 458-465.

20. Núñez-Acuña, G.; Aballay, A.E.; Hégaret, H.; Astuya, A.P.; Gallardo-Escárate, C. Transcriptional responses of Mytilus chilensis exposed in vivo to saxitoxin (STX). J. Molluscan Stud. 2013, 79, 323-331.

21. Manfrin, C.; de Moro, G.; Torboli, V.; Venier, P.; Pallavicini, A.; Gerdol, M. Physiological and molecular responses of bivalves to toxic dinoflagellates. Invertebr. Surival J. 2012, 9, 184-199.

22. Suárez-Ulloa, V.; Fernández-Tajes, J.; Manfrin, C.; Gerdol, M.; Venier, P.; Eirín-López, J.M. Bivalve omics: State of the art and potential applications for the biomonitoring of harmful marine compounds. Mar. Drugs 2013, 11, 4370-4389.

23. Aguilera-Belmonte, A.; Inostroza, I.; Franco, J.M.; Riobo, P.; Gomez, P.I. The growth, toxicity and genetic characterization of seven strains of Alexandrium catenella (Whedon and Kofoid) Balech 1985 (Dinophyceae) isolated during the 2009 summer outbreak in southern Chile. Harmful Algae 2011, 12, 105-112.

24. Varela, D.; Paredes, J.; Alves-de-Souza, C.; Seguel, M.; Sfeir, A.; Frangópulos, M. Intraregional variation among Alexandrium catenella (Dinophyceae) strains from southern Chile: Morphological, toxicological and genetic diversity. Harmful Algae 2012, 15, 8-18.

25. Jedlicki, A.; Fernandez, G.; Astorga, M.; Oyarzun, P.; Toro, J.E.; Navarro, J.M.; Martinez, V. Molecular detection and species identification of Alexandrium (Dinophyceae) causing harmful algal blooms along the Chilean coastline. AoB Plants 2012, 2012, pls033.

26. Wang, D.Z. Neurotoxins from marine dinoflagellates: A brief review. Mar. Drugs 2008, 6, 349-371.

27. Oshima, Y. Postcolumn derivatization liquid-chromatographic method for paralytic shellfish toxins. J. AOAC Int. 1995, 78, 528-532.

28. Navarro, J.M.; Aguila, B.L.; Machmar, F.; Chaparro, O.R.; Contreras, A.M. Dynamic of intoxication and detoxification in juveniles of Mytilus chilensis (Bivalvia: Mytilidae) exposed to paralytic shellfish toxins. Aquat. Living Resour. 2011, 24, 93-98.

29. Brousseau, P.; Pellerin, J.; Morin, Y.; Cyr, D.; Blakley, B.; Boermans, H.; Fournier, M. Flow cytometry as a tool to monitor the disturbance of phagocytosis in the clam Mya arenaria hemocytes following in vitro exposure to heavy metals. Toxicology 2000, 142, 145-156.

30. Cao, A.; Mercado, L.; Ramos-Martinez, J.I.; Barcia, R. Primary cultures of hemocytes from Mytilus galloprovincialis Lmk.: Expression of IL-2R $\alpha$ subunit. Aquaculture 2003, 216, 1-8.

31. Lebel, J.M.; Giard, W.; Favrel, P.; BoucaudCamou, E. Effects of different vertebrate growth factors on primary cultures of hemocytes from the gastropod mollusc, Haliotis tuberculata. Biol. Cell 1996, $86,67-72$.

32. Cajaraville, M.P.; Pal, S.G. Morphofunctional study of the haemocytes of the bivalve mollusc Mytilus galloprovincialis with emphasis on the endolysosomal compartment. Cell Struct. Funct. 1995, 20, 355-367.

33. Hine, P.M. The inter-relationships of bivalve haemocytes. Fish Shellfish Immunol. 1999, 9, 367-385. 
34. Le Foll, F.; Rioult, D.; Boussa, S.; Pasquier, J.; Dagher, Z.; Leboulenger, F. Characterisation of Mytilus edulis hemocyte subpopulations by single cell time-lapse motility imaging. Fish Shellfish Immunol. 2010, 28, 372-386.

35. Wang, Y.; Hu, M.; Chiang, M.W.; Shin, P.K.; Cheung, S.G. Characterization of subpopulations and immune-related parameters of hemocytes in the green-lipped mussel Perna viridis. Fish Shellfish Immunol. 2012, 32, 381-390.

36. Ford, S.E.; Bricelj, V.M.; Lambert, C.; Paillard, C. Deleterious effects of a nonPST bioactive compound(s) from Alexandrium tamarense on bivalve hemocytes. Mar. Biol. 2008, 154, 241-253.

37. Arumugam, M.; Romestand, B.; Torreilles, J.; Roch, P. In vitro production of superoxide and nitric oxide (as nitrite and nitrate) by Mytilus galloprovincialis haemocytes upon incubation with PMA or laminarin or during yeast phagocytosis. Eur. J. Cell Biol. 2000, 79, 513-519.

38. Hegaret, H.; Wikfors, G.H.; Soudant, P. Flow cytometric analysis of haemocytes from eastern oysters, Crassostrea virginica, subjected to a sudden temperature elevation II. Haemocyte functions: Aggregation, viability, phagocytosis, and respiratory burst. J. Exp. Mar. Biol. Ecol. 2003, 293, 249-265.

39. Lambert, C.; Soudant, P.; Choquet, G.; Paillard, C. Measurement of Crassostrea gigas hemocyte oxidative metabolism by flow cytometry and the inhibiting capacity of pathogenic vibrios. Fish Shellfish Immunol. 2003, 15, 225-240.

40. Lemasters, J.J.; Holmuhamedov, E. Voltage-dependent anion channel (VDAC) as mitochondrial governator-Thinking outside the box. Biochim. Biophys. Acta 2006, 1762, 181-190.

41. Huang, C.J.; Schild, L.; Moczydlowski, E.G. Use-dependent block of the voltage-gated $\mathrm{Na}^{+}$channel by tetrodotoxin and saxitoxin: Effect of pore mutations that change ionic selectivity. J. Gen. Physiol. 2012, 140, 435-454.

42. Huang, M.; Song, X.; Zhao, J.; Mu, C.; Wang, L.; Zhang, H.; Zhou, Z.; Liu, X.; Song, L. A C-type lectin (AiCTL-3) from bay scallop Argopecten irradians with mannose/galactose binding ability to bind various bacteria. Gene 2013, 531, 31-38.

43. Li, M.; Li, C.; Ma, C.; Li, H.; Zuo, H.; Weng, S.; Chen, X.; Zeng, D.; He, J.; Xu, X. Identification of a $C$-type lectin with antiviral and antibacterial activity from pacific white shrimp Litopenaeus vannamei. Dev. Comp. Immunol. 2014, 46, 231-240.

44. Tanguy, M.; McKenna, P.; Gauthier-Clerc, S.; Pellerin, J.; Danger, J.M.; Siah, A. Sequence analysis of a normalized cDNA library of Mytilus edulis hemocytes exposed to Vibrio splendidus LGP32 strain. Results Immunol. 2013, 3, 40-50.

45. Toubiana, M.; Gerdol, M.; Rosani, U.; Pallavicini, A.; Venier, P.; Roch, P. Toll-like receptors and MyD88 adaptors in Mytilus: Complete cds and gene expression levels. Dev. Comp. Immunol. 2013, 40, 158-166.

46. Duchemin, M.B.; Auffret, M.; Wessel, N.; Fortier, M.; Morin, Y.; Pellerin, J.; Fournier, M. Multiple experimental approaches of immunotoxic effects of mercury chloride in the blue mussel, Mytilus edulis, through in vivo, in tubo and in vitro exposures. Environ. Pollut. 2008, 153, 416-423.

47. Gagnaire, B.; Thomas-Guyon, H.; Renault, T. In vitro effects of cadmium and mercury on Pacific oyster, Crassostrea gigas (Thunberg), haemocytes. Fish Shellfish Immunol. 2004, 16, 501-512.

48. Latire, T.; le Pabic, C.; Mottin, E.; Mottier, A.; Costil, K.; Koueta, N.; Lebel, J.M.; Serpentini, A. Responses of primary cultured haemocytes from the marine gastropod Haliotis tuberculata under 10-day exposure to cadmium chloride. Aquat. Toxicol. 2012, 109, 213-221. 
49. Mottin, E.; Caplat, C.; Mahaut, M.L.; Costil, K.; Barillier, D.; Lebel, J.M.; Serpentini, A. Effect of in vitro exposure to zinc on immunological parameters of haemocytes from the marine gastropod Haliotis tuberculata. Fish Shellfish Immunol. 2010, 29, 846-853.

50. Olabarrieta, I.; L'Azou, B.; Yuric, S.; Cambar, J.; Cajaraville, M.P. In vitro effects of cadmium on two different animal cell models. Toxicol. in Vitro 2001, 15, 511-517.

51. Anderson, R.S.; Brubacher, L.L.; Calvo, L.M.R.; Burreson, E.M.; Unger, M.A. Effect of in vitro exposure to tributyltin on generation of oxygen metabolites by oyster hemocytes. Environ. Res. 1997, 74, 84-90.

52. Gagnaire, B.; Thomas-Guyon, H.; Burgeot, T.; Renault, T. Pollutant effects on Pacific oyster, Crassostrea gigas (Thunberg), hemocytes: Screening of 23 molecules using flow cytometry. Cell Biol. Toxicol. 2006, 22, 1-14.

53. Gomez-Mendikute, A.; Etxeberria, A.; Olabarrieta, I.; Cajaraville, M.P. Oxygen radicals production and actin filament disruption in bivalve haemocytes treated with benzo(a)pyrene. Mar. Environ. Res. 2002, 54, 431-436.

54. Blasco, D.; Levasseur, M.; Bonneau, E.; Gelinas, R.; Packard, T.T. Patterns of paralytic shellfish toxicity in the St. Lawrence region in relationship with the abundance and distribution of Alexandrium tamarense. Sci. Mar. 2003, 67, 261-278.

55. Cao, A.; Ramos-Martinez, J.I.; Barcia, R. In hemocytes from Mytilus galloprovincialis Lmk., treatment with corticotropin or growth factors conditions catecholamine release. Int. Immunopharmacol. 2007, 7, 1395-1402.

56. Sauvé, S.; Brousseau, P.; Pellerin, J.; Morin, Y.; Senécal, L.; Goudreau, P.; Fournier, M. Phagocytic activity of marine and freshwater bivalves: In vitro exposure of hemocytes to metals $(\mathrm{Ag}, \mathrm{Cd}, \mathrm{Hg}$ and Zn). Aquat. Toxicol. 2002, 58, 189-200.

57. Donaghy, L.; Hong, H.K.; Lambert, C.; Park, H.S.; Shim, W.J.; Choi, K.S. The known and unknown sources of reactive oxygen and nitrogen species in haemocytes of marine bivalve molluscs. Fish Shellfish Immunol. 2010, 28, 87-97.

58. Vandesompele, J.; de Preter, K.; Pattyn, F.; Poppe, B.; van Roy, N.; de Paepe, A.; Speleman, F. Accurate normalization of real-time quantitative RT-PCR data by geometric averaging of multiple internal control genes. Genome Biol. 2002, 3, research0034.1-research0034.11.

59. Núñez-Acuña, G.; Gallardo-Escárate, C. Identification of immune-related SNPs in the transcriptome of Mytilus chilensis through high-throughput sequencing. Fish Shellfish Immunol. 2013, 35, 1899-1905.

60. Núñez-Acuña, G.; Tapia, F.J.; Haye, P.A.; Gallardo-Escárate, C. Gene expression analysis in Mytilus chilensis populations reveals local patterns associated with ocean environmental conditions. J. Exp. Mar. Biol. Ecol. 2012, 420-421, 56-64.

(C) 2015 by the authors; licensee MDPI, Basel, Switzerland. This article is an open access article distributed under the terms and conditions of the Creative Commons Attribution license (http://creativecommons.org/licenses/by/4.0/). 